\title{
International Judicial Position: A Chance to Express Effective Ideas in the International Legal System
}

\author{
Roghieh Ebrahimi ${ }^{1}$ \& Hossein Sharifi Tarazkouhi ${ }^{2}$ \\ ${ }^{1}$ PhD Student of Public International Law, Imam Reza International University, Mashhad, Iran \\ ${ }^{2}$ Associated Professor, Department of Law, Tarbiat Modarres University, Tehran, Iran \\ Correspondence: Hossein Sharifi Tarazkouhi, Associated Professor, Department of Law, Tarbiat Modarres \\ University, Tehran, Iran. Email: hsharifit@yahoo.com
}

Received: September 2, 2016

Accepted: September 18, 2016

Online Published: October 17, 2016

doi:10.5539/mas.v11n2p1

URL: http://dx.doi.org/10.5539/mas.v11n2p1

\begin{abstract}
Each system component, which is in relation with human social life, is in mutual interaction with its environment and in a constant evolution and change. This uninterrupted move, which always led to the upswing whole system at the end, is implemented in the wake of its components with the requirements of human life. So it can be said that organizational development of international law that one of its achievements is the emergence of international tribunals as an embodiment of the maturity of relations between political units and their collective life, was a value flow and its result was the development of normative system of international law; an effective relationship between the structure and norm-cross in which each other will equip and grow. In this study, a thorough investigation into all aspects and intricacies of this effect is not desired. But only review the corner of the ocean in terms of cause and effect is included developing rules of international law.

In spite of the general meaning of "International Judicial Position" in this topic, our focus will be on the position of the Judges at the International court of justice as the main judicial organ of United Nations organization.
\end{abstract}

Keywords: international judicial system, international judges, individual opinion, impartiality

\section{Introduction}

The emergence of international courts and governments resorting to judicial dispute settlement procedure is one of the manifestations of the development of international relations and the growing acceptance certificate the legal order of international political relations in throughput. The courts today are so spread increasingly, regardless of valuable and familiar functions are a valuable opportunity for experts and scholars of international law to express thoughts, opinions and ideas through scientific writings. In fact, employment in the office of international judicial is a precious opportunity for scholars in an effort to develop norms and rules of international law, which is made possible through the structural development of this system. In response to why such is claimed it should be noted that the judges in the international courts such as the International Court of Justice properties, firstly able to do that merely by the presence as the international judges at the tribunal and employment status has been granted to them, secondly, the independence and impartiality of judges and the judicial system as a legacy which born at the national legal system and imported into the international legal system is an element which increase the validity of the thoughts and ideas of international judges.

\section{Facilities and Rights Granted to International Judges}

The first attempt to create a permanent international court took place in the 1890s. However, these efforts did not work only because the governments involved in The Hague Peace Conference of 1899 failed to agree on issues related to the assignment of judges. The establishment of the Permanent Court of International Justice in 1922 was the first global effort to establish an effective international legal order based on the court's judgments whose duties were subsequently followed by the International Court of Justice (Note 1). By the late 1950s, the court and its fifteen judges had an international concession in judicial settlement of disputes, however gradually found numerous courts so that even today the proliferation of international tribunal's frequency is spoken. Today, in the international judicial authorities there are about two hundred judicial seats which will increase with the inclusion of ad hoc judges (Mackenzie \& Sands, 2003, p. 274); however, compared with most domestic systems it is negligible, but in the international system that creating a permanent judicial court was in turn a result of 
intergovernmental relations development and eventual adoption of the legal order established political units such accelerated growth in the number of the courts that in principle will be increasing the number of international judges also led to the emergence of a system that some authors call it "international judiciary" (Allain, 1999, 1). Despite the multiplicity, the International Court of Justice still dominates the international judicial jurisdiction (Abi-Saab, 1996, 3) and referred to it as the World Court (Ibid.). That is why the seats in the World Court could be a unique opportunity for the international law scholars to express of their thought and ideas at universal level. In fact, a scholar who as an international judge enters in a court has a privilege compared to his counterparts; he has been awarded the concession by the organization. The importance of becoming a judge at the court is not only due to seize the opportunity of participating in the debates and dialectical negotiations with his or her fellow, but also is due to the opinions and ideas that he/she releases through a global Tribune and his/her opinions will be as a gift to be in the world's dialectical debates. It is certain that such an idea cannot be the same as the influence of what is written through a university professor expressed.

\subsection{Deliberations at the Court as a Manifestation of the Dialectical Process of Thought Based}

Based on the rules of the Statute of the International Court of Justice, the Court judges are elected from the finest legal scholars and each one follow a school of thought. The reference to Article 9 of the Statue of the court also proves the validity of such a claim; the last part of the article says:

".... The persons to be elected should... as a whole the representation of the main forms of civilization and of the principal legal systems of the world should be assured." In fact, these schools of thoughts those over time have increasingly expanding, rooted in legal positivism and natural law as two main schools of thoughts. The scholars who have different intellectual backgrounds and experiences will arrive in the place, which by the position they will be responsible for the administration of justice. Some say that the court is a place where we can hear the true voice of the law (Allott, 1996, 3); that is why we expect the expressions of the superior legal thoughts through the discussion that progressed at the Court. Legal debates and discourses is one of the ways to promote the best ideas, regardless of their particular school. The emergence of such debates can be seen in the court in two ways. First dialectical arguments in the Court occur in the context of deliberations. Each of the Court judges have the opportunity to express their ideas and to satisfy their counterparts, this is well established in a resolution dated 1976 concerning the Internal Judicial Practice of the Court. Everywhere in this document deals with the necessity of holding deliberations and judges debates about the issues and questions raised by the case.

One of the most important themes of the provisions contained in this document is the necessity and importance of the exchange of views of judges in each step of the procedure; which results in the issuance of judgments from the thoughts of the majority of intellectuals of the Court. Historically, the thoughts, which expressed at the court, might not always honorable, but they generally functioned as a light in the way of international law developments. In this sense, in any particular case a dialectical process flows through deliberations and express opposing ideas about the legal issues; this process as the emergence of conflict in the above-mentioned schools of thought will become a tool for judges to persuade their colleagues. Harry Edwards believes that cooperation between the judges is a process by which each of them will find out what are the others "Best Value" (Edwards, $2003,1640)$. He continues that, judges as members of the legal community have a common interest in understanding the rules correctly. Cooperation between judges is a process by which all points of their views will be revealing, it let the judges to review each other, and ultimately it will help to create conditions for achieving the substantive agreement (Ibid., 1645). According to Edwards Cooperation between the judges in the Court plays an important role in modulating individual policies and ideologies which are fanatically, because they allow to any of the judges with insights and different ideological philosophies to communicate, to listen and ultimately influence each other (ibid).

\subsection{The Individual Opinions of the Judges as Culmination of the Dialectical Process}

The culmination of this dialogue-based process is through another rating that International judges are to benefit from being a part of organization. As the complex discussions and debates over after numerous deliberations finally issued a judgment that is in fact the opinion of the international judges majority; but the constitutional rules of the Court is also considering the possibility of another issue; the possibility that giving another life to the dialectical process which has begun from secret deliberations at the Court. Article 57 of the Statute of the Court provides "If the judgment does not represent in whole or in part the unanimous opinion of the judges, any judge shall be entitled to deliver a separate opinion". The right to express individual opinions , that the pages of history reflects the vicissitude until the establishment of it on the Statute of the Court, has become a tool in the judges hands to voice their thoughts in the international community. The choice to append the individual judicial opinions is a right by which the judges practice to issue their opinion together with the court's judgment. In this 
regard, it seems dialectical process created within the Court extended to the international arena. An international judge who is not in tune with the thinking of the majority or failed to express his thought in all aspects of the judgment has another path to influence the minds in the international community. To put it more clearly, individual opinions of judges with the Court's judgment as a whole will lead to development and opening to the global debate among governments, politicians, international institutions and international law scholars and experts. Such debates among the subjects of international law takes place in the light of superior ideas, so that eventually pave the way for acceptance of the idea and thought regardless of its school. What is important is the persuasive value of ideas that will prove by the reliability of the reasoning and its links with the necessaries of international life. Thereby, superior thoughts eventually pave the way for the adoption of new norms and normative developments in the international legal system. In addition, it should be remembered that it is always possible that the future judgments of the court, as the majority opinions, will be the witness of applying of the opinions and ideas that now are in the minority position.

\section{The Independence and Impartiality of International Judges}

Power of thought by the international judges without respect to the independence and impartiality of the outcome is a function that is not a way to enter the international legal system. International judges either express their views through the judgment or by authority to explain their personal beliefs and issue their individual opinions, without maintaining their independence and impartiality not only is their thinking has no power of persuasion (Helfer \& Slaughter, 1997, 273) but also is generally considered illegitimately. Some believe that without the principle of independence all international tribunals will discredit (Franck, 1990, pp. 29-33). Although the proof of the independence of international judges is not the proof of the effectiveness of their ideas in the international legal system, it seems essential as one of the reasons for the credibility of the international community to validate the opinions and finally leveling the impact of it at the aforementioned normative system. In other words, a court that its members regardless of any political, economic, social act will be on a path that can resolve disputes fairly as well as establish legal principles also. This would enhance the authority and credibility of the court at the international community and governments would resort to judicial procedures for resolving disputes (Meron, 2011, p. 255). According to Theodore Meron, one of the elements of recognizing of an independent tribunal is the independence and impartiality of its judges in addition to ensuring conditions for preserving the independence of the legal entities as a whole (Ibid.). The right to access to an independent and impartial tribunal as a precondition for achieving fair is a general legal principle (Bassiouni, 2012, 604). Benefit from this right includes freedom of judges from any orientation and prejudice, so that, their activities quite impartially and independently of political or administrative controls be done. The political nature of international law shows the importance of guaranteeing the independence of the judiciary and international judges. Provisions of the Statute of every international court by setting and formulating qualification criteria for judges and also acknowledging the need for impartial and independent deal with the issue. In the words of one of the experts in the field, judicial independence and impartiality in the modern sense is a broad sense, so that on the one hand it refers to the impartiality of individual judges and on the other hand is an expression of judicial independence (Shetreet, 1985, 590).

\subsection{Impartiality of International Judges}

Individual independence against the parties is an aspect of the independence that is commonly referred to as impartiality. This means that special relationship with the parties may be caused prejudice and bias in decisions. Despite encouraging judges to observe all aspects of impartiality, still elaborate literature on the concept of impartiality does not exist (Hernandez, 2014, 130). In fact to start with this concept is so difficult from a legal point of view because everyone according to their own ideas of justice and law deal with it (ibid). In the International Court of Justice impartiality as one of the requirements of judicial independence, is the interpretation of activities without any effects or external interventions; so that, the international judge only rely on facts and the applicable law (Zimmermann and others, 2012, p. 207). Statute of the Court refers to this issue in Articles 16, 17 and 24. The first paragraph of Article 16 of the Statute provides: "No member of the Court may exercise any political or administrative function, or engage in any other occupation of a professional nature". This article deals with the wrongness of the activities out of the courtroom for the judges as an element, which may undermine the independence of judicial system. According to some authors such activities can be used as evidence of bias in the judicial process firstly and secondly in order to spend time on these activities may be interrupted judicial activities (Mackenzie, op.cit, 282). Generally, the statutes of all judicial tribunals discussed for this issue of a ban on the activities out of the courts; but the degree to which there are differences for such a ban, which in some cases referred to the term "limitations" rather than "Prohibition" is more appropriate.

Another manifestation of prejudice international judges that according to documents clearly establish 
international tribunals violated the principle of impartiality of the judge is previous connection with the parties or the subject filed with the court. The first and second paragraph of Article 17 of the Statute of the Court also provided that: "No member of the Court may act as agent, counsel, or advocate in any case. No member may participate in the decision of any case in which he has previously taken part as agent, counsel, or advocate for one of the parties, or as a member of a national or international court, or of a commission of enquiry, or in any other capacity". Developing international legal system that is still small compared with domestic judicial systems makes it more complicated. This means that it is not so far from the mind that a judge of an international court deal with issues faced with previously; whether as a diplomat or a counselor or academic, such communication will be challenging. However, consideration of judgments issued by the Court show that despite protests that governments or concerned parties to present some of the judges in the Court proceedings but the doubt in impartiality of judges based on their previous connection with the subject rarely has become a controversial topic.

The Court also indicates the need to safeguard the principle of impartiality of international judges and therefore, we cannot ignore the objective of disqualification of judges in the application of Article 17. For example, Judge Jessup in the case of "Temple of Preah Vihear" in 1962 due to its association with the case disqualified himself. Also in the case of "Certain Questions of Mutual Assistance in Criminal Matters" in 2008, one of the judges for a close relationship with one of the parties of dispute disqualified himself. Judge Rau, who previously was in the Security Council as the representative of India and deals with issues related to the dispute between Iran and Britain, In the case of "Anglo-Iranian Oil" 1952 disqualified himself (Hernandez, op.cit., 144-145).

In International Court of Justice concerns about bias and loss of impartiality of judges has been largely introduced about ad hoc judges and national judges. In the international judiciary system against internal judiciary system that any relationship with the parties directly lead to disqualification of the judge, the existence of such a relationship is officially recognized. Article 31 of the Statute of the Court is a provision that allows states to choose an ad hoc Judge and of course, the government has continued use of it (Smith, 2005: 197). This Regulation, which was adopted to safeguard the principle of equality between the parties, and today, has become an integral part of the international legal system based on instability created doubts on judicial independence. Loder argues against the validity of ad hoc judges and believes that it considers arbitration procedures rather than the idea of Justice and the acceptance of such a provision to the judiciary system will cause be close to arbitration procedures (Schwebel, 1999, p. 889). In contrary opinions, "nationality" of judges has been identified as a factor in his final decision. It is said that, the influence has three ways: 1) psychologically, this means that the acceptance of international impartiality of the judge to his government is very difficult; because they, in addition to emotional ties with their governments, often acted as a diplomat, counsel or politician in their country. Therefore, even if their goodwill be assumed, they still could consider the dispute from other parties' point of view hardly. 2) Economically, in the sense that the judge may be stimulated with financial issues. Penalties can be one of the consequences of the judge's action against his government's willingness. The judge may also lose government support for re-election or maybe face with his government's unkindness after the ending of his term of office. 3) Elective effects, meaning that the governments as entities competent to nominate the judges can choose the suggested judge among special persons and ensure lack of independence of the judge's thought (Posner \& Defigueiredo, 2005, p. 608).

According to some scholars, despite we cannot completely deny claims of bias in ad hoc judges who have the citizenship of the parties, but still the International Court of Justice has a great respect in the minds of subjects of international law (Ro, 1969, p. 235); hence, maybe we account the governments ensure about their benefit from the same opportunities to express and explain their points as one of the positive aspects of using ad hock judges (ibid). Fabien Gelinas wrote in an article and quoted: Judges who are appointed by the parties can act as an interpreter; a translator who in his broad sense deals to describe the subtleties and does enlightenment of legal culture and his appointed government's law in the minds of others (Gelinas, 2010, pp. 517-518). Judge Lachs to answer questions about the impartiality of judges with the nationality of the parties, in a separate opinion that was annexed to the Court's decision in the case of military and paramilitary activities in Nicaragua in 1986 said: "No need to stress that a judge is bound to neutrality. Governments should ensure that there would not be any bias and prejudice on. Although judges are the representative of various legal schools, and may have different ideas about rights and justice and be inspired by conflicting theories or moving in different directions, still with utmost sincerity are required to apply the law to the cases before them". (ICJ Reports, 1986, Sep.Op. Judge Laches: 148)

Judge Higgins believes that although many elements of uncertainty and confusion surrounding the issue of neutrality waging, there is no concrete document to prove that the Court systematically voted in favor of 
preferences or have been trained by the appointed government or government suppliers (Higgins, 2005, p. 135). Of course, she adds, the international judge is not responsible for any government. The idea that the judgment of the judge in a particular case is because of nationality, race or religion, is very wrong (Higgins, 2006, p. 3). A look at the performance of the Court shows examples of violation of the claims on the independence of national and ad hoc Judges (Samore, 1956, p. 200). For example, in the case of Anglo-Iranian Oil Company in 1952, Sir Arnold Mc. Nair who was a British man accompanied with the majority voted against the interests of their own countries. Finally, Article 24(1) of the Statute of the Court provides that: "If, for some special reason, a member of the Court considers that he should not take part in the decision of a particular case, he shall so inform the President. ".

This article, which its implementation might be said is one of the best symbols of neutrality of International Judge; is a provision that relays on the judges commitment to fulfill the duties impartially and conscientiously convenience. In fact, the assessment of each particular case and relying on the conscience for being impartial, all show the trust of international community to the judges of the Court. Theodor Meron believes that the disqualification of the judge has two aspects. The first case is when the judge concludes that for some reason cannot have independent judgment. At this time surely must declare his incapacity. But the other aspect, which is more important is that, despite the judge's ability to make impartial decisions, the others accuse him of favoring in the judgment, logically (Meron, Op.Cit., 261). He believes that in such a case the judge must exclude his jurisdiction to make a decision, not because that is not able to perform his judicial duties, but to safeguard the integrity of the judicial court (Ibid.).

\subsection{Independence of International Judges}

In the light of the political nature of international relations, that has spread its shadow over the international legal system, the need to anticipate measures to minimize external pressure on the international legal system and guarantee its independence becomes more apparent. Among these is the need for the compound to maintain the independence of judges who are selected and through their respective governments reached the courts, and their reassignment in the trial also is tied to their government's confirm. Some believe that respect for independence in the selection of judges and their tenure is the most important criterion of independence in an International Court (Keohane \& Others, 2000, 460). As mentioned earlier, in the statute of all courts there are attempt to set binding norms to ensure the independence of judges; but the judges before entering the courts experience electoral process that, according to many, is a political ritual that has little transparency (Mackenzie \& Sands, Op.Cit., 277-278). The governments introduce international judicial candidates. MacKenzie wrote in this regard that a government that has chosen an individual to participate in an international court and candidates him considers the important issue that the same person may one day sit in contentious case related to its national interests; hence, the government has always viewed such people, as they are involved in their national interests (ibid).

The General Assembly and the Security Council for renewable nine-years appoint fifteen judges in International Court of Justice. From the criticism to the regulations of the Court selection is that, the individuals concerned are selected from a list provided by national groups, which typically composed of four nominees from the government, and they are dependent on the government and not independent of its control and domination (Damrosch, 2000, 579). However, delegating this task to the national groups was with the aim of to make the process more interactive and to ensure proper distribution of representatives. That is why Damrosch proposes that the decisions of national groups should be taken in a specialized fashion (Ibid.).

Another criticism is proposed about non-compliance with the provisions of Article 9 of the statute. According to Rosenne, the article is modified version of the principle of "equitable geographical distribution" that is provided in the United Nations Charter as a basic principle for allocation seats of the elements of this reference (Rosenne, 2003, 44). Referring to the political significance of the elections in court, Robinson writes, while Article 9 of the Statute says clearly about the need for a wide selection of judges representing main forms of civilization and principal legal system, the words of this text have been overcome by politics (Davis, 2003, p. 279) and there is an unwritten procedures to allocate five seats of the Court to the judges of permanent members of the Security Council. Some have gone so far that considered the judges as captured by political positions of their respective governments and believe that they have misunderstood the role of judicial and arbitration (Swart, 2006, pp. 69-70). It is also said that the international judge, who for re-election needs to government support, may decide in cases such that to reserve the interests of government and its other states allies (Meron, Op.Cit., 257).

Considering these concerns Theodore Meron, strongly recommends that judges act more carefully in decision-making; especially when they are dealing with issues that are related to their home country or a country that is supporting their candidacy. He adds that such advice is not meant to reform the judges' comments, but 
means the need for making a reasonable decision and in accordance with the legal basis so that, the judge not be suspected to bias (Ibid., 257-258). Looking to Article 2 of the Statute of the Court, we understand that independence is the first necessary condition for the election of judges at this tribunal. However, the question is that, to answer all raised doubts, how can we establish to judge the independence of the candidates presented. According to some researchers, the provision probably emphasizes that the person on the Court should act independently after appointing as a judge (Amerasinghe, 2001, p. 336). That is why that person as soon as he entered the Court will benefit from the political privileges and immunities.

Arguably, it should be noted that the inescapable shades of politics that influence on the international legal system should not be viewed in a negative sense. It seems beyond all regulations set, what can only be to guarantee the independence and impartiality of the judge is the emphasis on the selection from those how have "high moral character"; because in the end the judge's morality and conscience would ensure his independence, and that is why under Article 20 of the Statute, the obligation of judges to serve conscientiously is explained.

\section{Conclusion}

The most sublime goal that each of scholars of different scientific fields is followed is to express their ideas which ultimately affected in specialized scientific field. In this regard, each found a way to be heard. Some wrote their thinking and some others used the power of words in this rout. International law as one of modern science is not an exception. One of the factors that can influence the thoughts expressed in the field of international law is the allocation of legal scholars as the international judge. In response to the question of how the appointment can lead to influence the academic excellence in international legal system, we looked some effective factors and saw that the opportunity that is granted through the international judicial position is a blessing that belongs to judges. One of the opportunities that the judges have is the secret deliberations that lead a process of legal dialogue between them, which finally pave the way of ideas to the international legal system. In other words, through the same path the judges can affect their colleague's opinions by expressing reasonable and superior ideas and finally, affect the issuance of the Court's judgment, which its function is obvious in the future developments of international legal system. Another tool is allowance of the individual opinions enclosure with the Court's judgment. Expressing such opinions is in fact the culmination of a dialectical process that mentioned earlier. As clarification, the dialectical process created within the Court will be extended to the global arena and ultimately leads to leveling path to take best idea, thought it would take effect regardless of schools of thought each belongs. We should also mention the international judge's independence and impartiality as one of the essential characteristics of the above mentioned seats, that is essential as one of the arguments for the credibility of the international community to validate the above mentioned opinions and finally to leveling the impact of the aforementioned normative system.

\section{References}

Abi-Saab, G. (1996). The International Court as a World Court. In Vaughan Lowe and Malgosia Fitzmaurice (Eds.), Fifty Years of the International Court of Justice: Essays in honour of Sir Robert Jennings, Cambridge University Press.

Allain, J. (1999). Judicial Independence in Practice: The Case of Judge Odio Benito, Vice-President of Costa Rica. Revue de droit international de science diplomatiques et politiques, 77.

Allott, P. (1996). The International Court and the Voice of Justice. In Vaughan Lowe and Malgosia Fitzmaurice (Eds.), Fifty Years of the International Court of Justice: Essays in honour of Sir Robert Jennings, Cambridge University Press.

Amerasinghe, C. F. (2001). Judges of International Court of Justice: Election and Qualifications, Leiden Journal of International Law, 14.

Bassiouni, M. C. (2012). Introduction to International Criminal Law. Martinus Nijhoff Publishers. (2nd Eds.).

Damrosch, L. F. (2000). The Election of Thomas Buergenthal to the International Court of Justice. American Journal of International Law, 94.

Edwards, H. T. (2003). The Effects of Collegiality on Judicial Decision Making. University of Pennsylvania L aw Review, 151(5).

Gelinas, F. (2010). Independence and Impartiality in International Adjudication. In Adam Dodek and Iorne Sossin (Eds.). Judicial Independence in Context, Irwin Law INC.

Franck, T. M. (1990). The Power of Legitimacy Among Nations, Oxford University Press.

Helfer, L. R., \& Anne, M. S. (1997). Toward a Theory of Effective Supranational Adjudication. Yale Law Journal, 
107(2).

Hernandez, G. (2014). The International Court of Justice and the Judicial Function, Oxford University Press.

Higgins, R. (2005). Alternative Perspectives on the Independence of International Courts: Remarks. 99 Proceeding of the American Society of International Law.

Higgins, R. (2006). Reflection from the International Court. In M. Evans, International Law, (2nd Eds.). Oxford University Press.

Keohane, R. O., Andrew, M., \& Anne-Marie, S. (2000). Legalized Dispute Resolution: Interstate and Transnational. International Organization, 54(3).

Mackenzie, R., \& Philippe, S. (2003). International Courts and Tribunals and the Independence of the International Judge. Harvard International Law Journal , 44(1).

Meron, T. (2011). The Making of International Criminal Justice: A View from the Bench, Oxford University Press.

Posner, E. A., \& Miguel, F. P. D. F. (2005). Is the International Court of Justice Biased? The Journal of Legal Studies, 34(2).

Ro, S. II (1969). Voting Behavior of National Judges in International Courts. American Journal of International Law, 63(2).

Rosenne, S. (2003). The World Court, What It is and How It Works. (6th Eds.). In Terry D. Gill, Martinus Nijhoff publishers.

Samore, W. (1956). National Origins v. Impartial Decisions: A Study of World Court Holdings. Chicago-Kent Law Review, 34(3).

Schwebel, S. M. (1999). National Judges and the Judges ad hoc of the International Court of Justice. International and Comparative Law Quarterly, 48(4).

Shetreet, S. (1985). Judicial Independence: New Conceptual Dimensions and Contemporary Challenges. In Shimon Shetreet and Jules Eschenes (Eds.), Judicial Independence: The Contemporary Debate, Martinus Nijhoff Publishers.

Smith, A. M. (2005). Judicial Nationalism in International Law: National Identity and Judicial Autonomy at the ICJ. Texas International Law Journal, 40.

Swart, M. (2006). Judges and Lawmaking at the International Criminal Tribunals for the former Yugoslavia and Rwanda. Doctoral thesis, Faculty of Law, Leiden University.

Thirlway, H. \& Law, T. (2012). The Statute of the International Court of Justice: A Commentary. (2nd. Eds), Oxford University Press. In A. Zimmermann, K. Oellers-Frahm, C. Tomuschat \& C. J. Tams (Eds.).

Military and Paramilitary Activities in and against Nicaragua (Nicaragua v. United States of America), I.C.J. Reports (1986). Merits, Sep. Op. of Judge Lachs.

Note

Note 1. Hereafter "the Court"

\section{Copyrights}

Copyright for this article is retained by the author(s), with first publication rights granted to the journal.

This is an open-access article distributed under the terms and conditions of the Creative Commons Attribution license (http://creativecommons.org/licenses/by/4.0/). 